\title{
THE NEED FOR SELF-EDUCATION AS THE DRIVING FORCE OF SUSTAINABLE PROFESSIONAL DEVELOPMENT OF FUTURE ENGLISH LANGUAGE TEACHERS
}

The article deals with the issue of the need for self-education in the context of teacher training. In a rapidly changing world there is a great demand for teachers who are strongly motivated and interested in their professional development. It is stated that any good pre-service training cannot prepare teachers to the challenges in their profession. The focus of this study is on the need for self-education as a source of selfactualization and professional growth. The main purpose of this work is to highlight the importance of teacher development and define basic conditions that help to form future English teachers' need for self-education as the driving force of their sustainable professional development.

The author emphasizes that it is vital important to support teachers' professional growth during these difficult times created by the COVID-19 pandemic. That's why it is quite essential to be aware of the new ways of teaching English in the pandemic, teachers pedagogic needs and what works in relation to the professional development of English teachers.

Self-education begins with students' awareness of the need to work on themselves. An important feature of professional self-education is that it cannot be imposed. An intense interest in this activity must be developed as well as a deep need must be formed. Special attention is paid to the idea that the need for professional self-education is not innate, it is formed in the process of human socialization and arises as a natural need of the developing personality and it is a stimulus for further self-development. The formation of the future teacher's need for professional self-education is a controlled process and its effectiveness depends on the content and organization of the educational process of the university. The author states that a necessary and sufficient condition for the need for self-education is to create a situation of success, an atmosphere of creativity and friendliness. The emphasis is made on the conditions at university when every student believes in own strength and would like to become better and reach real heights in the future profession as an English teacher. The conditions of emergency of the need for self-education are revealed.

Key words: need for self-education, teacher training, future English language teacher, professional development, self-study.

Formulation of the issue. Current social, spiritual and economic changes in the context of Ukraine's European choice lead to significant shifting paradigms within higher pedagogical education, which is designed to train a new generation of teachers. Such teachers are supposed to be humane, competent, highly competitive, deeply motivated and interested in their professional development. Teachers are expected to teach in increasingly multicultural classrooms and to work effectively within heterogeneous groups; to place greater emphasis on integrating students with special learning needs in their classrooms; to make more effective use of information and communication technologies for teaching; to engage more in planning within evaluative and accountability frameworks; and to do more to involve parents in school educational process.

High requirements to the quality of teachers' training are defined in Ukrainian government documents "Law on General Secondary Education", "Law on Higher Education", State Program "Teacher", the National Doctrine of Education of Ukraine in the XXI century. The similar requirements are described in the recommendations of the international community: DeSeCo (Definition and Selection of Competencies: Theoretical and Conceptual Foundations), "Common European Framework of Reference for Languages: Learning, Teaching, Assessment", European Qualifications Framework, "A Memorandum on Lifelong Learning".

No matter how excellent pre-service training for teachers is, it is quite obvious that it cannot prepare teachers for all the challenges and never-ending problems they will face throughout their careers. Therefore, education systems seek to provide future teachers with opportunities for effective professional self-development in order to maintain a high standard of teaching and to retain a high-quality teacher staff.

Analysis of research publications. Understanding professional self-education as an integral part of teacher training is described in the works of $\mathrm{V}$. Bondar, O. Dubasenyuk, V. Lozova, N. Nychkalo, O. Pekhota, 
V. Semichenko, S. Sysoeva, T. Sushchenko and others. The researchers have identified the requirements for professional training of a future teacher, a prominent place among which belongs to the constant enrichment of his personality, improving skills through self-education and self-growth.

Recently, scientific research in the field of self-education of future teachers has intensified. The analysis of these studies allows to distinguish the following points: professional self-education of students during pedagogical practice (A. Mikaberidze, $\mathrm{O}$. Treshchev), features of self-education of student's youth (Yu. Babansky, I. Zyazyun, A. Kalinichenko, A. Sushchenko), specifics of postgraduate students' self-education (G. Shirokova), pedagogical guidance of students' self-educational activity (R. Garifyanov, S. Kabanova, Z. Sepcheva), professional and moral self-education of future teachers (S. Dansheva, O. Kucheryavy, A. Raimkulova, L. Sushchenko, M. Tkachova, O. Yatsiy).

Despite the undeniable importance of all scientific works in this area, we would like to state that the problem of formation in future English language teachers of the need for professional self-education has been insufficiently explored in the research literature. This paper takes into consideration the lack of similar study in the context of the COVID-19 pandemic which has caused new professional realities and challenges to English language teachers' community.

Purpose of the article. The study aims to highlight the importance of teacher development and define basic conditions that help to form future English teachers' need for self-education as the driving force of their sustainable professional development.

Presentation of the main research material. Whether you are a teacher, a teacher educator, a student teacher, a newly-qualified teacher, your professional development is an important part of your career and a crucial element in maintaining your growth in the English Language Teaching profession. Teaching is a highly sophisticated skill which needs life long learning and practice.

There are a lot of articles and books in literature addressing how to be excellent at teaching. Different people talk from different points of views, address different aspects of teaching and discuss different methodologies in teaching. According to Dr Dengsheng Zhang, despite the variety of methods, it goes without saying that three types of skills are vital to quality teaching: command of knowledge, attitude and communication skills. All those methods and strategies of teaching can be classified into the three categories in one way or another. The scientist believes that attitude is no less important than the other two skills and even more important in terms of teaching driving force. Attitude means commitment to education and professional teaching, stay current with field knowl- edge, persistent to improve knowledge, persistent to provide best teaching resources and materials, love to support students, enthusiastic in teaching, keep on trying new technology in teaching, open to critics and feedbacks and lifetime pedagogical reflection and research [1].

As practice shows there is a broad definition of professional development among teachers. Professional development is defined as activities that develop an individual's skills, knowledge, expertise and other characteristics as a teacher. The definition recognises that professional growth can be provided in many ways. It can be available in the forms of courses, workshops or formal qualification programmes, through collaboration between schools or teachers. The professional development of English language teachers can be provided through coaching/mentoring, collaborative planning and teaching, and the sharing of good practices. Nowadays it can be made not only via face-to-face communication but also by means of the Internet and mobile connection, virtual platforms such as Zoom, Teams, Skype, WhatsApp, Telegram, Discord and others.

The COVID-19 pandemic has affected educational systems around the world in different ways. Teachers were forced to teach students both in schools and at home, requiring them to make significant adjustments to their work and imposing the need for a variety of skills to navigate the new ways of teaching. It is quite necessary not only to understand what changes are needed in the current teaching and learning but also realise the ways in which the teacher training can be provided to help future teachers develop a reimagined teaching, which draws from the best of traditional approaches, innovative practices, and insights from remote learning to shape new, flexible, agile hybrid deep learning models [2].

It goes without saying that it is vital important to support teachers' professional growth during these difficult times created by the global pandemic. According to Karagianni's research, teacher development is contingent on a number of factors, which are often ignored, such as teachers' personal motivation, centrality of teachers' emotions, involvement of teachers in self-develpoment activities and collaboration with colleagues [3].

Current trends and new targets in the field of education require a rethinking of the sense and content of teacher training. We agree with L. Sushchenko that the ability to self-development and self-education on a constant basis, the ability to work in an atmosphere of continuous creative search becomes extremely important for future teachers [4]. Self-education begins with students' awareness of the need to work on themselves. An important feature of professional self-education is that it cannot be imposed. An intense interest in this activity must be developed as well as a deep need must be formed. The need for 
professional self-education is not innate, it is formed in the process of human socialization and arises as a natural need of the developing personality and it is a stimulus for further self-development. The higher the level of personal development, the more acutely a future teacher feels the need for self-education, which is the driving force of sustainable professional development.

S. Yelkanov believes that the source of teacher's self-education is the need for self-change and self-improvement. Among a number of principal reasons influencing the emergence of this need, the scientist identifies the requirements for teachers, which are put forward by headmasters, colleagues, students and their parents. Every school has its own style of high demands on the teacher's personality and the quality of his work. This style is considered to bethe first condition that encourages self-education. $\mathrm{S}$. Yelkanov emphasizes that the need for self-education gives rise to the next actions of the teacher in the sphere of self-improvement. The desire to be not just a teacher, but a master of pedagogical work plays a special role in the emergence of this need [5].

Among the important impulses that have a significant impact on the motivation of professional self-education, O. Bordenyuk gives preference to pedagogical/teaching practice, during which students feel an increased interest in teaching, lack of general, psychological and pedagogical knowledge, some inconsistency of their personal qualities to the chosen profession. The scientist emphasizes that by joining the school educational process with various forms of activity, gaining a certain amount of knowledge, having pedagogical practice, students better understand the requirements of society to their training and profession. Therefore, their desire for self-education and improvement of professionally significant qualities is becoming stronger [6].

A necessary condition for the need for professional self-education is the transition from the position "I am a student" to the position "I am a teacher". O. Kucheryavy reports that the future teacher's need for self-education is impossible without the development of his professional self-awareness. The scientist proposes to begin this process by organizing the freshmen's study of requirements for the personality of a teacher. The researcher believes that the method of developing students' professional self-awareness should be constructed as a process of clash of views of teachers and future teachers, which causes the latter emotional feelings about the imperfection of their own professional "I", the desire to develop it [7].

The formation of the future teacher's need for professional self-education is a controlled process and its effectiveness depends on the content and organization of the educational process of the university. According to I. Vnukova, psychological and pedagogical disciplines along with pedagogical practice have significant opportunities for the formation of this need. The scientist points out that the need for pedagogical self-education is most active when the student is involved in real pedagogical situations, in which he must use not only theoretical knowledge but also own professionally significant qualities and abilities, skills and abilities. In such situations the student gets used to a new position - the position of a teacher. The student's awareness of the real requirements of a pedagogical activity to his personality together with a positive attitude to these requirements creates a certain professional and emotional orientation, the urgent need for self-education [8].

The need for self-education can be formed by creating conditions for the natural formation of the student as a subject of professional development. The perception of oneself as a subject of individual professional development is revealed in the future teacher's desire and ability to analyze, adjust and improve own professional growth constantly. We totally agree with $\mathrm{O}$. Pekhota, who identifies the conditions among the external psychological and pedagogical ones that contribute to the future teacher's professional self-development, and hence the emergence of the need for professional self-education:

- orienting the purposes, content and technologies of teachers' training on acquisition of humanistic values of professional activity; introduction into the content of professional training the system of concepts and ideas that aim the future teachers at professional self-development:

- using the theoretical model of the teacher's individuality as a scheme-route for the organization of psychological and pedagogical support of professional self-study, and further self-improvement of the future teacher;

- compiling a professional self-portrait in order to integrate the consequences of personal and professional self-stydy;

- developing strategies and tactics of future teacher's professional self-development, united in the individual program of professional growth for any stage of professional activity [9].

Conclusions. It is impossible to encourage professional self-education by obtrusion, violence or edification. A necessary and sufficient condition for the need for self-education is to create a situation of success, an atmosphere of creativity and friendliness. It is necessary to create such conditions at university that every student, believing in their own strength, would like to become better and reach real heights in the future profession as an English teacher. Needs arise as a consequence of properly organized activities of the individual, the practice of his behavior, his relationships with other people. Therefore, the activity, which is characterized by a creative nature, the ability to see themselves in action, satisfaction with the results of own work, the ability to form a sense 
of self-worth cause the emergence of the need to work on yourself as a future teacher. The special atmosphere in the academic group, the establishment of co-creative relations between teachers and students, providing opportunities for each student to identify and develop individual characteristics are important conditions for the formation of the need of future English language teachers in professional self-education.

\section{References:}

1. Zhang D. The Three Driving Forces of Teaching. URL: $\quad$ https://users.monash.edu.au/ dengs/ teaching/GCHE/part2-5.pdf (дата звернення: 22.06.2021).

2. New Ways of Teaching: Skills teachers need in order to teach in 2020-2021. URL: https://americas.britishcouncil.org/ sites/default/ files/final-new_ways_of_teaching_250521_to_be_ published_0.pdf?_ga $=\mathbf{2} .140355259 .982787941$. 1624261192-198262349. 1603370537 (дата звернення: 22.06.2021).

3. Karagianni E. Teacher development and emotions: An ICT-based reflective/collaborative approach. Unpublished PhD Thesis, National and Kapodistrian University of Athens, Greece.
URL: https://thesis.ekt.gr/thesisBookReader/ id/31746\#page/1/mode/2up (дата звернення: 22.06.2021).

4. Сущенко Л.О. Культурологічна спрямованість профресійної підготовки майбутнього педагога вектор безперервного процесу його самовдосконалення. Педагогіка формування творчої особистості у вищій і загальноосвітній школах. 2017. Вип. 55 (108). С. 324-332.

5. Елканов С.Б. Основы профессионального самовоспитания будущего учителя. Москва : Просвещение, 1989. 189 с.

6. Борденюк О.В. Формування у студентів потреби у профресійному самовдосконаленні. Радянська школа. 1986. № 5. С. 34-35.

7. Кучерявий О.Г. Теоретичні і методичні основи організації професійного самовиховання майбутніх вихователів дошкільних закладів і вчителів початкових класів : дис. ... д-ра пед. наук : 13.00.04. Київ, 2002. 406 с.

8. Внукова І. Організація самовиховання у студентів педвузу. Рідна школа. 2003. № 4. C. $40-42$.

9. Пехота Е.Н. Индивидуализация профессионально-педагогической подготовки учителя. Київ : Вища школа. 1997. 281 с.

\section{Шиманович І. В. Потреба у професійному самовихованні як рушійна сила професійного розвитку майбутнього вчителя англійської мови \\ У статті розглядається питання необхідності самовиховання в контексті підготовки вчителів.} У світі, що швидко змінюється, великий попит на вчителів, які мають сильну мотивацію та зацікавлені у своєму професійному розвитку. Зазначається, що грунтовні знання, вміння, навички, які здобувач вищої освіти отримує в університеті, не можуть підготувати майбутніх учителів до викликів в їхній профресії. Основна увага в цьому дослідженні зосереджена на необхідності самовиховання як джерела самореалізації та профресійного зростання. Основна мета роботи - висвітлити важливість розвитку вчителів та визначити основні умови, які допомагають сформувати потребу майбутніх учителів англійської мови в самовихованні як рушійній силі їх сталого професійного розвитку.

Автор наголошує, що життєво важливо підтримувати професійне зростання вчителів у ці важкі часи, створені пандемією COVID-19. Доцільно знати нові способи викладання англійської мови в умовах пандемії, педагогічні потреби вчителів та фрактори стимулювання професійного розвитку викладачів англійської мови.

Самовиховання починається з усвідомлення студентами необхідності працювати над собою. Важливою особливістю професійного самовиховання є те, що воно не може бути нав'язано. Потрібно розвивати постійний інтерес до цієї діяльності, а також формувати глибоку потребу. Особлива увага приділяється думці, що потреба в професійному самовихованні не є вродженою, вона формується в процесі соціалізації людини і виникає як закономірна потреба особистості, що розвивається, і є стимулом для подальшого саморозвитку. Формування потреби майбутнього вчителя у профресійному самовихованні є контрольованим процесом і його ефективність залежить від змісту та організації освітнього процесу в університеті. Автор заявляє, що необхінною та достатньою умовою потреби в самовихованні є створення ситуації успіху, атмосфрери творчості та доброзичливості. Акцент робиться на умовах в університеті, коли кожен студент вірить у власні сили і хотів би стати кращим та досягти реальних висот у майбутній професії вчителя англійської мови.

Ключові слова: потреба в самовихованні, підготовка вчителя, майбутній вчитель англійської мови, професійний розвиток, самоаналіз. 